\title{
NiEJEDNOLITE STOSOWANIE DEFINICJI POJĘĆ PRAWNYCH W PRAWIE PODATKOWYM
}

\begin{abstract}
Streszczenie. W niniejszym artykule autor przedstawia problemy ze stosowaniem definicji legalnych oraz operatywnych definicji prawnych. Analiza orzecznictwa sądów administracyjnych oraz praktyki organów podatkowych wskazuje na niejednolite stosowanie tych definicji przy rozstrzyganiu konkretnych spraw podatkowych. Konsekwencją dla takiego ustalania rozumienia pojęć prawnych zawartych w ustawach podatkowych jest brak przewidywalności rozstrzygnięć dla podatników (szerzej adresatów norm prawnopodatkowych).
\end{abstract}

Słowa kluczowe: definicje legalne, operatywne definicje, prawo podatkowe

1. WPROWADZENIE

Dla każdego podatnika (szerzej: adresata normy prawnopodatkowej) załatwiającego swoją sprawę podatkową istotne jest, aby rezultaty stosowania prawa podatkowego były dla niego przewidywalne. Innymi słowy, podmioty rozstrzygające jego sprawę podatkową powinny w pełni urzeczywistniać postulat pewności tego prawa ${ }^{1}$. Nie trzeba nikogo przekonywać, że pogląd ten jest rezultatem jednej z cech charakteryzujących prawo podatkowe - duży stopień ingerencji w prawa i wolności jednostki².

* Uniwersytet Wrocławski.

${ }^{1}$ H. Filipczyk, Postulat pewności prawa w wykładni operatywnej prawa podatkowego, Warszawa 2013, s. 63.

${ }^{2}$ B. Brzeziński, Rozstrzyganie na korzyść podatnika jako zasada wykładni prawa podatkowego. Próba analizy, [w:] Ex iniuria non oritur ius. Księga ku czci profesora Wojciecha Łączkowskiego, red. A. Gomułowicz, J. Małecki, Poznań 2003, s. 255. 
W procesie stosowania prawa podatkowego niewątpliwie podstawową płaszczyzną dla próby osiągnięcia przewidywalności jego rezultatów jest język prawny danej ustawy podatkowej, który powinien być fundamentem dla prawidłowej komunikacji między stronami stosunku prawnopodatkowego $^{3}$. Zgodność we wzajemnej komunikacji może być osiągnięta w sytuacji, gdy albo każda ze stron identycznie interpretuje pojęcia zawarte w treści danej ustawy podatkowej, albo gdy wśród podmiotów rozstrzygających sprawy podatkowe - sądy administracyjne, czy też organy podatkowe ${ }^{4}$ - jednolicie ustalane są znaczenia ustawowych określeń. Bez tego trudno mówić o jakiejkolwiek przewidywalności rezultatów stosowania prawa podatkowego przez podmioty rozstrzygające sprawy podatników (szerzej adresatów norm prawnopodatkowych).

Istotnym zagadnieniem dla ustalania sposobu rozumienia pojęć w prawie podatkowym jest ich definiowanie przez podmioty stosujące prawo podatkowe. Zagadnienie to należy rozumieć na dwóch płaszczyznach. Pierwsza z nich dotyczy ustalania znaczenia konkretnych pojęć zawartych w ustawie podatkowej w oparciu o definicje legalne. W doktrynie prawa podatkowego wskazuje się, że charakter prawa podatkowego wymusza częste korzystanie przez ustawodawcę, w procesie tworzenia prawa podatkowego, $\mathrm{z}$ definicji zawartych w treści ustaw podatkowych ${ }^{5}$. Podstawowe determinanty konstruowania definicji w danej ustawie podatkowej, w procesie tworzenia prawa podatkowego przez ustawodawcę, zostały uregulowane w rozporządzeniu w sprawie "Zasad techniki prawodawczej”. Zgodnie $z \$ 146$ rozporządzenia w sprawie „Zasad techniki prawodawczej” definicje formułuje się w treści ustawy, gdy dane określenie jest: wieloznaczne, nieostre; znaczenie danego określenia nie jest powszechnie zrozumiałe; oraz istnieje potrzeba ustalenia nowego znaczenia danego określenia ${ }^{7}$. Przypadki, w których formułuje się definicje pojęć prawnych wskazują, że definicje

${ }^{3}$ Por. R. Mastalski, Stosowanie prawa podatkowego, Warszawa 2008, s. 75-76.

${ }^{4}$ Podmioty te są podmiotami stosującymi prawo podatkowe.

${ }^{5}$ P. Borszowski, Wprowadzanie definicji legalnych $w$ prawie podatkowym - zagadnienia wyjściowe, „Wrocławsko-Lwowskie Zeszyty Prawnicze” 2016/2017, s. 221.

${ }^{6}$ Rozporządzenie Prezesa Rady Ministrów z dnia 20 czerwca 2002 r. w sprawie „Zasad techniki prawodawczej” (t.j. Dz.U. z 2016 r., poz. 283), zwane dalej: rozporządzenie w sprawie „Zasad techniki prawodawczej”; P. Borszowski, Wprowadzanie..., s. 224 i n.

${ }^{7}$ Szerzej zob. P. Borszowski, Definiowanie pojęć w prawie podatkowym jako ograniczenie obszaru nieostrości, „Wrocławsko-Lwowskie Zeszyty Prawnicze” 2017/2018, s. 193. 
mają przyczyniać się do zwiększania komunikatywności danego aktu normatywnego.

Natomiast druga płaszczyzna ustalania sposobu rozumienia pojęć prawnych zawartych w ustawach podatkowych, dotyczy interpretowania tych pojęć w oparciu o definicje stworzone przez podmioty rozstrzygające sprawy podatkowe na potrzeby konkretnej sprawy (ad hoc). Definicje te można określić mianem operatywnych, bowiem nawiązując do koncepcji operatywnego prawa $^{8}$, tak skonstruowane definicje są rezultatem stosowania stanowionego prawa i mają określoną moc wiążącą.

Posługiwanie się definicjami legalnymi pojęć prawnych przez ustawodawcę w prawie podatkowym jest charakterystyczne dla tej gałęzi prawa" Jednak nie zawsze w ustawie podatkowej dane pojęcie prawne ma swoją definicję albo odesłanie do definicji spoza konkretnego aktu normatywnego. W związku $\mathrm{z}$ tym, w procesie ustalania znaczeń niezdefiniowanych pojęć prawnych zawartych w ustawie podatkowej, dużym wyzwaniem jest dla podmiotów stosujących prawo podatkowe urzeczywistnienie postulatu pewności prawa podatkowego, a więc jego przewidywalności i jednolitości stosowania. Dlatego też cel niniejszego opracowania to analiza sposobu stosowania definicji pojęć prawnych przez podmioty rozstrzygające sprawy podatkowe.

Hipotezą badawczą w niniejszym artykule jest stwierdzenie, że podmioty rozstrzygające sprawy podatkowe niejednolicie stosują definicje pojęć prawnych w prawie podatkowym.

\section{Niejednolite STOSOWANIE DEFINICJI LEGALNYCH POJĘĆ PRAWNYCH W PRAWIE PODATKOWYM}

Definicje legalne zajmują szczególne miejsce w systemie prawa podatkowego ${ }^{10}$, bowiem stanowią narzędzie do precyzji języka prawnego. $\mathrm{Za}$ ich pomocą po pierwsze, ustawodawca w procesie tworzenia prawa próbuje pozbawić tekst prawny późniejszych wątpliwości w procesie jego

${ }^{8}$ J. Wróblewski, Rozumienie prawa i jego wykładnia, Wrocław 1990, s. 14-16.

${ }^{9}$ P. Borszowski, Pomiędzy elastycznościa przepisów prawa podatkowego a definicjami legalnymi, [w:] Ksiega jubileuszowa Profesor Krystyny Sawickiej. Gromadzenie i wydatkowanie środków publicznych. Zagadnienia finansowoprawne, red. W. Miemiec, Wrocław 2017, s. 475.

${ }^{10}$ Por. A. Bielska-Brodziak, Kłopoty z definicjami legalnymi, [w:] O. Bogucki, S. Czepita (red.), System prawny a porządek prawny, Szczecin 2008, s. 160. 
stosowania ${ }^{11}$, a więc dąży on do zwiększenia komunikatywności tekstu ustawy podatkowej. Ponadto konsekwencją definiowania pojęć prawnych przez ustawodawcę jest „uzyskanie pewności normatywnej w takim sensie, iż definicja ta wyjaśnia znaczenie danego pojęcia i jest stosowana $\mathrm{w}$ danym obszarze w taki sposób, jak określił normodawca" ${ }^{12}$. Po drugie, podmioty stosujące prawo podatkowe, przy pomocy definicji dokonują interpretacji danego tekstu prawnego a następnie odkodowują normę prawną. Ważne jest, że definicje legalne pojęć prawnych narzucają interpretatorowi tekstu prawnego konkretną dyrektywę wykładni, ponieważ definicje te zawierają regułę ogólną oraz abstrakcyjną, a więc obowiązują one powszechnie.

Proces stosowania legalnych definicji przez podmioty rozstrzygające sprawy podatkowe ma swoje konkretne etapy. Wśród tych etapów istotne jest tzw. poszukiwanie definicji legalnej analizowanego pojęcia zawartego w ustawie podatkowej. Na tym etapie występuje znacząca wątpliwość: czy podmiot ten ma poszukiwać definicji wyłącznie w treści ustawy podatkowej, której dotyczy konkretny stan faktyczny, czy też powinien poszukiwać tej definicji w innych ustawach podatkowych a nawet w całym systemie prawa? Trudno jest udzielić jednoznacznej odpowiedzi na to pytanie, bowiem występuje tu zagadnienie mocy wiążącej definicji pojęć prawnych $\mathrm{z}$ innych aktów normatywnych a na tym polu istnieją znaczące rozbieżności zarówno wśród doktryny prawa ${ }^{13}$, jak również orzecznictwa sądów administracyjnych oraz rozstrzygnięć organów podatkowych, które będą analizowane.

Sądy administracyjne nie są zgodne co do stosowania legalnych definicji pojęć prawnych wyrażonych w innych ustawach niż stosowana w danym

${ }^{11}$ B. Brzeziński, Szkice z wykładni prawa podatkowego, Gdańsk 2002, s. 48.

${ }^{12}$ P. Borszowski, Korzystanie z określeń nieostrych przy tworzeniu definicji legalnych w prawie podatkowym, [w:] J. Korczak (red.), Cywilizacja administracji publicznej. Ksiegga jubileuszowa $z$ okazji 80-lecia urodzin prof. nadzw. UWr dra hab. Jana Jeżewskiego, Wrocław 2018, s. 67.

${ }^{13}$ Jedni przedstawiciele doktryny prawa wskazują, że legalna definicja danego pojęcia wiąże na gruncie całego systemu prawa (J. Wróblewski, Zagadnienia teorii wykładni prawa ludowego, Warszawa 1959, s. 246). Natomiast można wskazać odmienny pogląd, zgodnie z którym konkretna legalna definicja wiąże wyłącznie obszar danej gałęzi prawa (M. Zieliński, Wykładnia prawa. Zasady, reguły, wskazówki, Warszawa 2017, s. 212). Z kolei doktryna prawa podatkowego podkreśla się, że legalna definicja wiąże wyłączę ten akt prawny, w którym została wyrażona, w związku z tym korzystanie bez wyraźnego odwołania w tekście danej ustawy podatkowej do definicji spoza tej ustawy jest niedopuszczalne (B. Brzeziński, Podstawy wykładni prawa podatkowego, Gdańsk 2008, s. 72-73). 
przypadku ustawa podatkowa. Nie budzi wątpliwości sądów administracyjnych, że w przypadku zastosowanego w danej ustawie podatkowej odesłania do definicji zawartej w innym akcie normatywnym taka definicja ma moc wiążącą ${ }^{14}$. Rozbieżność w orzeczeniach sądów administracyjnych dostrzegalna jest w sytuacji braku jakiegokolwiek odesłania. W tym zakresie występują zarówno stanowiska aprobujące korzystanie z „obcych” definicji wyrażonych $\mathrm{w}$ innych ustawach ${ }^{15}$, jak również negujące takie postępowanie ${ }^{16}$.

Wskazane rozbieżności co do korzystania $\mathrm{z}$ definicji legalnych na potrzeby niezdefiniowanych pojęć prawnych - w sytuacji braku wyraźnego odesłania w treści ustawy podatkowej do definicji zawartej w innym akcie normatywnym - powodują, że adresat normy prawnopodatkowej może mieć uzasadnione wątpliwości, co do rozstrzygnięć jego spraw podatkowych przez podmiot stosujący prawo podatkowe. Trudno bowiem mówić o przewidywalności rozstrzygnięć, skoro w procesie stosowania prawa podatkowego niekonsekwentnie posługuje się legalnymi definicjami niezdefiniowanych pojęć prawnych zwartych w konkretnych ustawach podatkowych.

\section{NiejedNOLITE STOSOWANIE OPERATYWNYCH DEFINICJI} POJĘĆ PRAWNYCH W PRAWIE PODATKOWYM

W literaturze przedmiotu zostały przeanalizowane sposoby interpretowania przepisów prawa podatkowego przez sądy administracyjne w sytuacji, gdy nie ma definicji legalnej konkretnego pojęcia w danej ustawie podatkowej ${ }^{17}$. Tym samym, podmioty te tworzą operatywne definicje pojęć prawnych, dokonując tego w dominującym zakresie w oparciu o tzw. potoczne rozumienie pojęcia prawnego ${ }^{18}$. Jednak ze względu na ramy ni-

${ }^{14}$ Np. wyrok NSA z dnia 13 czerwca 2013 r., I GSK 677/12 (CBOSA) oraz wyrok WSA w Gliwicach z dnia 24 stycznia 2018 r., III SA/Gl 955/17 (CBOSA).

${ }^{15}$ Zob. wyrok WSA w Rzeszowie z dnia 7 listopada 2017 r., I SA/Rz 611/17 oraz wyrok WSA w Warszawie z dnia 29 czerwca 2017 r., VIII SA/Wa 348/17 (CBOSA).

${ }^{16}$ M.in. wyrok NSA z dnia 7 października 2011 r., I GSK 597/10 (CBOSA) i wyrok WSA: w Gliwicach z dnia 2 grudnia 2011 r., III SA/Gl 714/11 oraz we Wrocławiu z dnia 31 stycznia 2014 r., I SA/Wr 1768/13 (CBOSA).

${ }^{17}$ A. Bielska-Brodziak, Interpretacja tekstu prawnego na podstawie orzecznictwa podatkowego, Warszawa 2009, s. 25-39.

${ }^{18} \mathrm{~W}$ literaturze przedmiotu zostało już zbadane, że w przypadku ustalania potocznego rozumienia danych pojęć przez orzecznictwo występują trzy źródła rozumienia tych pojęć w oparciu o: 1) opinie biegłych językoznawców; 2) intuicji językowej; 3) słowników językowych - A. Bielska-Brodziak, Interpretacja..., s. 25. 
niejszego artykułu kwestia tworzenia operatywnych definicji w prawie podatkowym zostanie pominięta, a uwaga będzie skoncentrowana wyłącznie $\mathrm{w}$ aspekcie ich stosowania.

Stosowanie operatywnych definicji pojęć prawnych przez podmioty stosujące prawo podatkowe de facto występuje w dwóch sytuacjach. Pierwsza $\mathrm{z}$ nich dotyczy braku definicji legalnej w całym systemie prawa, natomiast druga związana jest $\mathrm{z}$ brakiem definicji legalnej $\mathrm{w}$ danej ustawie podatkowej, ale definicja ta występuje w innym akcie normatywnym.

Pierwsza z tych sytuacji, czyli braku występowania definicji legalnej danego pojęcia w całym systemie prawa jest dość klarowna, bowiem podmiot stosujący prawo podatkowe nie ma innego wyboru, jak tylko skonstruowanie i zastosowanie operatywnej definicji danego pojęcia. Druga ze wskazanych sytuacji można określić mianem zjawiska przełamania definicji legalnej, czyli niezastosowanie definicji legalnej występującej w systemie prawa ${ }^{19}$.

Dla stosowania operatywnych definicji pojęć prawnych w prawie podatkowym istotne jest postrzeganie zagadnienia tzw. autonomii prawa podatkowego, bowiem w przypadku aspektu terminologii zastosowanej w ustawach podatkowych można wskazać na zjawisko tzw. autonomii pojęciowej prawa podatkowego ${ }^{20}$. Dlatego też z tego twierdzenia można wyprowadzić dwa rozbieżne wnioski. Po pierwsze, w przypadku braku legalnej definicji danego pojęcia w ustawie podatkowej, ze względu na autonomię prawa podatkowego, nie należy korzystać $\mathrm{z}$ definicji legalnych zawartych $\mathrm{w}$ innych aktach normatywnych. W konsekwencji „W sytuacji poważnej wątpliwości należy przede wszystkim odwołać się znaczenia nadanego [...] przez język naturalny" ${ }^{21}$. Po drugie, $\mathrm{w}$ analogicznym przypadku niezdefiniowania danego pojęcia na gruncie ustawy podatkowej, należy korzystać z definicji legalnych zawartych w innych aktach normatywnych, chyba że ustawodawca wyraźnie ukształtował nowe znaczenie tego pojęcia na gruncie ustawy podatkowej ${ }^{22}$.

${ }^{19} \mathrm{~Np}$. Interpretacja Indywidualna Dyrektora Izby Skarbowej w Katowicach z dnia 12 lutego 2015 r., IBPP4/443-545/14/EK, LEX nr 184803453 oraz Interpretacja Indywidualna Dyrektora Izby Skarbowej w Łodzi dnia 7 stycznia 2015 r., IPTPP3/443A-75/14-4/BJ, LEX nr 184802581.

${ }^{20}$ A. Bartosiewicz, R. Kubacki, Granice autonomii prawa podatkowego, „Glosa. Przegląd prawa gospodarczego" 2004, nr 1, s. 28.

${ }^{21}$ Zob. M. Zirk-Sadowski, Problem autonomii prawa podatkowego w orzecznictwie NSA, „Przegląd Orzecznictwa Podatkowego” 2004, nr 2, s. 117.

${ }^{22}$ Por. W. Nykiel, Autonomia prawa podatkowego (wybrane zagadnienia), [w:] T. Dębowska-Romanowska, A. Jankiewicz (red.), Konstytucja, ustrój, system finansowy państwa. Księga pamiątkowa ku czci prof. Natalii Gajl, Warszawa 1991, s. 401. 
Dla podmiotów stosujących prawo podatkowe autonomia prawa podatkowego jest niejednolicie rozumiana, a w związku z tym rzutuje to na kwestię stosowania operatywnych definicji pojęć prawnych. W związku z tym, wśród podmiotów stosujących prawo podatkowe występują postulaty wskazujące, że ze względu na autonomię prawa podatkowego przy ustalaniu definicji pojęć prawnych z ustaw podatkowych należy to czynić w oderwaniu od innych gałęzi prawa ${ }^{23}$. Ponadto można wskazać twierdzenia, zgodnie z którymi autonomia prawa podatkowego dotyczy wyłącznie ustawodawcy i jego swobody tworzenia definicji legalnych w ustawach podatkowych ${ }^{24}$. W związku z tym, można stwierdzić, że o autonomii prawa podatkowego można wyłącznie mówić w wymiarze tworzenia, a nie stosowania prawa podatkowego.

Podobnie jak w przypadku stosowania definicji legalnych, niejednolite stosowanie operatywnych definicji pojęć prawnych determinuje, że podatnik może mieć uzasadnione wątpliwości, co do rozstrzygnięć jego spraw podatkowych przez podmiot stosujący prawo podatkowe.

4. WOLA USTAWODAWCY, CZYLI MIĘDZY DEFINICJĄ LEGALNĄ A DEFINICJĄ OPERATYWNĄ

Kolejną kwestią istotną dla stosowania definicji pojęć prawnych w prawie podatkowym jest zagadnienie „woli ustawodawcy” w rozumieniu pojęć prawnych zawartych w ustawach podatkowych. Kwestia ta jest o tyle kluczowa, że wpływa zarówno oddzielnie na stosowanie definicji legalnych i operatywnych definicji pojęć prawnych, jak również na wybór pomiędzy zastosowaniem definicji legalnej a operatywnej definicji. Podmiot stosujący prawo podatkowe musi bowiem przeanalizować, czy wobec braku definicji w danej ustawie podatkowej należy przyjąć domniemanie, że wolą ustawodawcy jest rozumienie konkretnego pojęcia wyrażonego w tekście ustawy podatkowej zgodnie z językiem naturalnym, czy też odrzucenie tego domniemania i przyjęcie, że należy stosować definicję legalną z innej ustawy.

${ }^{23}$ M.in. wyrok WSA w Lublinie z dnia 21 lutego 2017 r., I SA/Lu 934/16 (CBOSA) oraz wyrok WSA w Gdański z dnia 5 października 2016 r., I SA/Gd 975/16 (CBOSA).

${ }^{24}$ M.in. uchwała NSA z dnia 6 marca 2017 r., I FPS 8/16 (CBOSA), wyrok NSA z dnia 14 grudnia 2016 r., I GSK 1148/16 (CBOSA), wyrok WSA w Gliwicach z dnia 26 października 2017 r., III SA/Gl 764/17 (CBOSA), wyrok WSA w Gliwicach z dnia 27 listopada 2017 r., I SA/Gl 944/17 (CBOSA), wyrok WSA w Gliwicach z dnia 1 marca 2018 r., III SA/Gl 920/17 (CBOSA) oraz wyrok WSA w Gdańsku z dnia 21 grudnia 2016 r., I SA/Gd 928/16 (CBOSA). 
W doktrynie prawa podatkowego podkreśla się, że w sytuacji braku definicji legalnej konkretnego pojęcia w ustawie podatkowej, przyjmuje się domniemanie o potocznym rozumieniu tego pojęcia, które jest zgodne $\mathrm{z}$ wolą ustawodawcy ${ }^{25}$. Innymi słowy, podmiot stosujący prawo podatkowe w sytuacji braku definicji legalnej danego pojęcia w ustawie podatkowej powinien zastosować operatywną definicję tego pojęcia.

Jednak w orzecznictwie sądów administracyjnych występują rozstrzygnięcia skrajnie rozbieżne - zarówno uznające możliwość korzystania z legalnych definicji spoza danej ustawy podatkowej ${ }^{26}$, jak również negujące taką możliwość ${ }^{27}$. W związku z tym, można wskazać na dwojakie rozumienie pojęcia „woli ustawodawcy” przez judykaturę. Pierwszy z nich „wola ustawodawcy" jako uzasadnienie dla stosowania operatywnych definicji pojęć prawnych w prawie podatkowym - skoro w danej ustawie podatkowej pewne pojęcie prawne nie zostało zdefiniowane to wolą ustawodawcy jest skonstruowanie i zastosowanie operatywnej definicji tego pojęcia ${ }^{28}$. Natomiast drugi ze sposobów, „wola ustawodawcy” jako zanegowanie możliwości stosowania operatywnych definicji pojęć prawnych w prawie podatkowym - w takiej sytuacji wolą ustawodawcy było posłużenie się wyłącznie legalną definicją zawartą w innych ustawach niż stosowana ustawa podatkowa ${ }^{29}$.

Podmioty stosujące prawo podatkowe posługują się argumentem „woli ustawodawcy” dla zaaprobowania stosowania zarówno definicji legalnych, jak również operatywnych definicji pojęć prawnych wyrażonych w treści ustawy podatkowej. W związku z tym, argument ten może uzasadniać skrajnie rozbieżne sposoby ustalania znaczeń pojęć prawnych w prawie podatkowym.

${ }^{25}$ B. Brzeziński, Uwagi o znaczeniu definicji w prawie podatkowym, [w:] R. Mastalski (red.), Księga Jubileuszowa Profesora Marka Mazurkiewicza. Studia $z$ dziedziny prawa finansowego, prawa konstytucyjnego i ochrony środowiska, Wrocław 2001, s. 229; B. Brzeziński, Podstawy..., s. 75.

${ }^{26}$ M.in. wyrok NSA z dnia 15 grudnia 2015 r., I GSK 1303/15 oraz wyrok WSA w Gliwicach z dnia 19 stycznia 2016 r., III SA/Gl 20141/15 (CBOSA).

${ }^{27}$ M.in. wyrok WSA: w Poznaniu z dnia 31 października 2017 r., I SA/Po 424/17 w Warszawie z dnia 9 czerwca 2017 r., VIII SA/Wa 233/17 (CBOSA)

${ }^{28} \mathrm{~Np}$. wyrok NSA z dnia 15 grudnia 2015 r., I GSK 1303/15, CBOSA.

${ }^{29}$ Np. wyrok WSA w Poznaniu z dnia 31 października 2017 r., I SA/Po 424/17, CBOSA. 
Sposób rozumienia pojęć prawnych w prawie podatkowym jest jednym $\mathrm{z}$ najistotniejszych etapów procesu stosowania prawa podatkowego. Jednolite stosowanie definicji, zarówno legalnych, jak i operatywnych przez podmioty stosujące prawo podatkowe będzie urzeczywistniać postulat pewności prawa podatkowego. Jednolitości w stosowaniu tych definicji jest gwarantem dla podatnika (szerzej adresata normy prawnopodatkowej), że rozstrzygnięcie jego sprawy podatkowej, przynajmniej w aspekcie rozumienia pojęć będzie przewidywalne.

Dokonana analiza orzecznictwa sądów administracyjnych oraz praktyki organów podatkowych jednoznacznie wskazuje na niejednolite stosowanie legalnych definicji oraz operatywnych definicji pojęć zawartych $\mathrm{w}$ treści danej ustawy podatkowej. Stosowanie to dotyczy sytuacji nieistnienia definicji legalnej pojęcia prawnego w jednej ustawie podatkowej oraz nieuregulowanie ewentualnego odesłania do innej regulacji prawnej zawierającej definicję tego pojęcia. Należy stwierdzić, że przyczyną tego stanu jest brak zasad co do stosowania tych definicji. Podmioty stosujące prawo podatkowe „po omacku” stosują definicje pojęć prawnych. Niepokojące są tak bardzo skrajnie rozbieżne poglądy co do stosowania legalnych definicji pojęć prawnych, czy też operatywnych definicji pojęć prawnych.

Trudne do zaakceptowania jest to, że podmioty rozstrzygające sprawy podatkowe przy stosowaniu definicji legalnych, czy też operatywnych definicji pojęć prawnych powołują się na „wolę ustawodawcy”. Samo w sobie określenie „woli ustawodawcy” może stanowić obszar wielu wątpliwości interpretacyjnych ${ }^{30}$, dlatego wydaje się nieprawidłowe odwoływanie się do tak niejasnego pojęcia przy ustalaniu sposobu rozumienia konkretnych pojęć prawnych w ustawach podatkowych. W konsekwencji odwoływanie się do „woli ustawodawcy” powoduje ogromne zamieszanie i de facto prowadzi do sytuacji bez wyjścia, bowiem każdy argument opierający się $\mathrm{o}$ „wolę ustawodawcy” może być zanegowany.

Podsumowując, należy stwierdzić, że podmioty stosujące prawo podatkowe (podmioty rozstrzygające sprawy podatkowe) niejednolicie stosuja definicje legalne i operatywne definicje pojęć prawnych. Podmioty te przedstawiają skrajnie rozbieżne stanowiska w tym zakresie. Dlatego też wydaje się niezbędne, aby podmioty rozstrzygające sprawy podatkowe spróbowały

${ }^{30}$ Zob. Z. Tobor, W poszukiwaniu intencji prawodawcy, Warszawa 2013. 
wypracować jednolite zasady dotyczące stosowania zarówno definicji legalnych, jak i tworzenia oraz stosowania operatywnych definicji pojęć prawnych w prawie podatkowym. Bez tego, po pierwsze, w dalszym ciągu będą występować problemy dla stosowania definicji pojęć prawnych w prawie podatkowym. Po drugie, podatnik (szerzej: adresat normy prawnopodatkowej) może mieć uzasadnione wątpliwości, co do rozstrzygnięć jego spraw podatkowych przez podmiot stosujący prawo podatkowe. Trudno bowiem mówić o przewidywalności rozstrzygnięć, skoro w procesie stosowania prawa podatkowego podmioty rozstrzygające sprawy podatkowe niekonsekwentnie posługują się definicjami legalnymi oraz operatywnymi definicjami pojęć prawnych, które nie mają swojej definicji w danej ustawie podatkowej.

\section{BIBLIOGRAFIA}

Bartosiewicz A., Kubacki R., Granice autonomii prawa podatkowego, „Glosa. Przegląd prawa gospodarczego" 2004, nr 1.

Bielska-Brodziak A., Interpretacja tekstu prawnego na podstawie orzecznictwa podatkowego, Warszawa 2009.

Bielska-Brodziak A., Kłopoty z definicjami legalnymi, [w:] O. Bogucki, S. Czepita (red.), System prawny a porzadek prawny, Szczecin 2008.

Borszowski P., Definiowanie pojęć w prawie podatkowym jako ograniczenie obszaru nieostrości, „Wrocławsko-Lwowskie Zeszyty Prawnicze” 2017, nr 8.

Borszowski P., Korzystanie z określeń nieostrych przy tworzeniu definicji legalnych $w$ prawie podatkowym, [w:] J. Korczak (red.), Cywilizacja administracji publicznej. Ksiega jubileuszowa z okazji 80-lecia urodzin prof. nadzw. UWr dra hab. Jana Jeżewskiego, Wrocław 2018.

Borszowski P., Pomiędzy elastycznościa przepisów prawa podatkowego a definicjami legalnymi, [w:] W. Miemiec (red.), Ksiega jubileuszowa Profesor Krystyny Sawickiej. Gromadzenie $i$ wydatkowanie środków publicznych. Zagadnienia finansowoprawne, Wrocław 2017.

Borszowski P., Wprowadzanie definicji legalnych w prawie podatkowym - zagadnienia wyjściowe, „Wrocławsko-Lwowskie Zeszyty Prawnicze” 2016, nr 7.

Brzeziński B., Podstawy wykładni prawa podatkowego, Gdańsk 2008.

Brzeziński B., Rozstrzyganie na korzyść podatnika jako zasada wykładni prawa podatkowego. Próba analizy, [w:] A. Gomułowicz, J. Małecki (red.), Ex iniuria non oritur ius. Księga ku czci profesora Wojciecha Eączkowskiego, Poznań 2003.

Brzeziński B., Szkice z wykładni prawa podatkowego, Gdańsk 2002.

Brzeziński B., Uwagi o znaczeniu definicji w prawie podatkowym, [w:] R. Mastalski (red.), Księga Jubileuszowa Profesora Marka Mazurkiewicza. Studia z dziedziny prawa finansowego, prawa konstytucyjnego i ochrony środowiska, Wrocław 2001.

Filipczyk H., Postulat pewności prawa w wykładni operatywnej prawa podatkowego, Warszawa 2013. 
Mastalski R., Stosowanie prawa podatkowego, Warszawa 2008.

Nykiel W., Autonomia prawa podatkowego (wybrane zagadnienia), [w:] T. Dębowska-Romanowska, A. Jankiewicz (red.), Konstytucja, ustrój, system finansowy państwa. Księga pamiątkowa ku czci prof. Natalii Gajl, Warszawa 1991.

Tobor Z., W poszukiwaniu intencji prawodawcy, Warszawa 2013.

Wróblewski, J., Rozumienie prawa i jego wykładnia, Wrocław 1990.

Wróblewski J., Zagadnienia teorii wykładni prawa ludowego, Warszawa 1959.

Zieliński M. Wykładnia prawa. Zasady, reguły, wskazówki, Warszawa 2017.

Zirk-Sadowski M., Problem autonomii prawa podatkowego w orzecznictwie NSA, „Przegląd Orzecznictwa Podatkowego" 2004, nr 2.

Summary. In this article, the author presents problems with the use of legal definitions and operative definitions of legal concepts. An analysis of the administrative courts' case law and the practice of tax authorities indicates the uneven application of these definitions in the settlement of specific tax cases. The consequence of such determination of the understanding of legal concepts contained in tax acts is the lack of predictability of decisions for taxpayers.

Keywords: legal definitions, operative definitions, tax law 